\title{
Effects of replacing soybean meal with canola meal for lactating dairy cows fed 3 different ratios of alfalfa to corn silage
}

\author{
E. M. Paula, ${ }^{1 *}$ () G. A. Broderick, ${ }^{2} \odot$ and A. P. Faciola ${ }^{1} \dagger \odot$ \\ ${ }^{1}$ Department of Animal Sciences, University of Florida, Gainesville 32611 \\ ${ }^{2}$ Broderick Nutrition and Research LLC, Madison, WI 53705
}

\begin{abstract}
Previous research has demonstrated that feeding canola meal $(\mathrm{CM})$ improves milk production and $\mathrm{N}$ utilization by lactating dairy cows when replacing solvent-extracted soybean meal (SBM). The objective of the present study was to evaluate whether CM would improve milk yield and components and $\mathrm{N}$ utilization, compared with SBM, at different ratios of alfalfa silage (AS) to corn silage (CS) fed to lactating dairy cows. Twenty-four multiparous Holstein cows averaging, at the beginning of the study (mean $\pm \mathrm{SD}$ ), $2.8 \pm 0.9$ parity, $684 \pm 56 \mathrm{~kg}$ of BW, $102 \pm 41 \mathrm{DIM}$, and $49 \pm 4$ $\mathrm{kg}$ milk/d, and 24 primiparous cows averaging (mean $\pm \mathrm{SD}) 565 \pm 46 \mathrm{~kg}$ of BW, $123 \pm 30 \mathrm{DIM}$, and $40 \pm$ $4 \mathrm{~kg}$ milk/d were blocked by parity and DIM. A cyclic changeover design with 4 replications of 2 blocks of treatments of 6 cows was used in an arrangement with 428 -d periods. Dietary treatments were arranged in a 3 $\times 2$ factorial design of 3 proportions of AS to CS as forage source (HAS $=$ high AS, $50 \%$ AS to $10 \%$ CS; MAS $=$ medium $\mathrm{AS}, 30 \% \mathrm{AS}$ to $30 \% \mathrm{CS}$; LAS = low $\mathrm{AS}$, $10 \%$ AS to $50 \% \mathrm{CS}$ ) and 2 protein supplements (CM vs. SBM). Diets were formulated to contain [dry matter (DM) basis]: $60 \%$ forage, 8 to $15 \%$ high-moisture corn, 2 to $5 \%$ soy hulls, $1.3 \%$ mineral-vitamin premix, $16 \%$ crude protein, and 31 to $33 \%$ NDF. Data from the last 2 weeks of each period were used to compute mean milk yield and composition, and efficiencies of feed conversion, for each cow in each period. Data for the other variables were collected during the last week of each period. All data were analyzed using the MIXED procedure of SAS (SAS Institute Inc., Cary, NC). Regardless of the forage source, replacing SBM with CM
\end{abstract}

Received May 10, 2019.

Accepted October 16, 2019.

*Current address: Instituto de Zootecnia, Centro APTA Bovinos de Corte, Rodovia Carlos Tonani, km 94, 14160-900, Sertãozinho, SP, Brazil.

†Corresponding author: afaciola@ufl.edu improved yields of milk, milk protein, and solids-notfat. Moreover, milk urea nitrogen concentration and urinary excretion of total $\mathrm{N}(\mathrm{g} / \mathrm{d}$ ) and urea $\mathrm{N}$ (\% of total urinary N) decreased when CM replaced SBM. An interaction effect occurred between forage source and protein supplements for apparent total-tract digestibility, and, overall, this effect was due to small differences in ingredient and chemical compositions of the diets. In addition, these differences had a minor effect on cow performance. Yields of milk and milk components were greatest for cows fed 50\% CS, intermediate for $30 \%$ CS, and lowest for $10 \%$ CS, indicating that, under the conditions of the present study, cows fed $50 \%$ CS in the diet (DM basis) had greater production compared with those fed $50 \%$ AS.

Key words: dietary protein, forage, milk protein, milk urea nitrogen

\section{INTRODUCTION}

Solvent-extracted soybean meal (SBM) is a protein supplement widely used in lactating dairy cows diets. However, canola meal (CM) has become a viable alternative protein supplement in North America (Martineau et al., 2013; Broderick et al., 2015) due to its high protein quality and increased availability (Lavergne and Oleson, 2018). Furthermore, when replacing SBM or other protein supplements with CM in diets of lactating dairy cows, an increase in milk yield (Huhtanen et al., 2011; Martineau et al., 2013; Broderick et al., 2015) and reductions in MUN concentration and urinary urea $\mathrm{N}$ (\% of total urinary $\mathrm{N}$ ) excretion have been observed (Broderick et al., 2015; Paula et al., 2018). The aforementioned results have shown a consistent improvement in production and $\mathrm{N}$ utilization by dairy cows fed $\mathrm{CM}$ compared with SBM. However, because of differences between SBM and CM in terms of RDP concentration (59 to $70 \%$ of $\mathrm{CP}$ for SBM, and 48 to $56 \%$ of $\mathrm{CP}$ for CM; Maxin et al., 2013; Broderick et al., 2016), coupled with the differences between alfalfa and corn silages in terms of RDP concentration (81 vs. $65 \%$ of CP; NRC, 2001) and also energy concentration, these silages could 
potentially influence ruminal $\mathrm{N}$ utilization, because of potential effects on ruminal ammonia $\mathrm{N}$ utilization for microbial protein synthesis. There is a need to better understand potential interactions between protein and forage sources when $\mathrm{CM}$ is the main protein source. Therefore, it is still unknown whether CM could effectively replace SBM in diets with greater inclusions of alfalfa silage (AS), and because of that knowledge gap, investigations into this potential interaction are needed.

Because of their high NPN concentration, forage sources such as AS influence ruminal $\mathrm{N}$ utilization, microbial protein production, MP, and AA supply, and consequently may affect milk yield and milk protein synthesis in high-producing dairy cows (Edmunds et al., 2013; Patton et al., 2014). In a meta-analysis evaluating the effects of CM vs. other protein supplements and also the effects of forage sources (grass or legume forage vs. corn or barley silages), Martineau et al. (2013) observed effects of forage source on milk protein responses. For example, only the combination of $\mathrm{CM}$ with grass silage or legume forages increased milk protein concentration compared with other protein supplements. It is well documented that corn silage (CS) and AS are the main forage sources fed to dairy cows in the United States (Dhiman and Satter, 1997; Groff and $\mathrm{Wu}, 2005$ ). Brito and Broderick (2006) and Brito et al. (2006) evaluated the effects of feeding dairy cows AS and CS in different proportions in diets with SBM as the main protein supplement. They observed that feeding cows diets with greater proportions of $\mathrm{AS}$, rather than CS, increased milk yield, total microbial protein, total essential AA flow at the omasal canal, and total $\mathrm{N}$ excretion. However, to our knowledge, the interactions between forage sources commonly used in North American diets (i.e., corn and alfalfa silages) with CM as a main protein supplement have not been evaluated, which underscores the importance of evaluating CM in CS- or AS-based diets on cows' performance and N utilization.

Therefore, the objectives of the present study were to determine (1) yields of milk and milk components when diets with 2 different forage sources (AS and CS) in 3 different proportions (50:10, 30:30, and 10:50; DM basis) were supplemented with SBM or CM, and (2) whether replacing AS with CS would alter $\mathrm{N}$ utilization and yields of milk and milk components by lactating cows. We hypothesized that (1) cows fed isonitrogenous diets with $\mathrm{CM}$ would produce more milk and reduce $\mathrm{N}$ excretion compared with cows fed SBM, and the increase in milk yield due to $\mathrm{CM}$ feeding would be less pronounced as CS replaces AS in the diet; and (2) greater proportions of CS rather than AS would improve $\mathrm{N}$ utilization and milk production by dairy cows.

\section{MATERIALS AND METHODS}

\section{Experimental Design}

Care and handling of all experimental animals were conducted under protocols approved by the University of Wisconsin Institutional Animal Care and Use Committee (Madison, WI).

At the beginning of the study, 24 multiparous cows with mean parity 2.8 (SD 0.9), BW $684 \mathrm{~kg}$ (SD 56), 102 DIM (SD 41), and $49 \mathrm{~kg}$ of milk/d (SD 4), and 24 primiparous cows with mean BW $565 \mathrm{~kg}$ (SD 46), 123 DIM (SD 30), and $40 \mathrm{~kg}$ of milk/d (SD 4), were used in this study. All 48 cows were blocked by parity and DIM into 8 groups of 6 cows each to obtain 4 groups of multiparous and 4 groups of primiparous cows and, within block, randomly allocated to the sequences of experimental treatments. A cyclic changeover design with 4 replications of 2 blocks of treatments of 6 cows was used in an arrangement with four 28-d periods (Design 16, Table 4, Davis and Hall, 1969; Supplemental Figure S1, https://doi.org/10.3168/jds.2019-16947). Dietary treatments were in a $3 \times 2$ factorial arrangement, consisting of 3 proportions of AS to CS as forage sources and 2 protein supplements. Thus, there were 8 cows per treatment per period, and a total of 32 observations for each of the 6 treatments during the trial. Chemical composition of the main ingredients of TMR is shown in Table 1. All diets were formulated to contain $16 \%$ $\mathrm{CP}$ and 60:40 forage-to-concentrate ratio (DM basis). The 6 experimental diets contained AS and CS in 3 different proportions (50:10, 30:30, and 10:50; DM basis), with SBM and CM as the major protein supplements. Dietary ingredients and chemical composition of the experimental diets are detailed in Table 2.

All cows were injected biweekly with recombinant bovine somatotropin (500 mg of Posilac, Elanco Animal Health, Greenfield, IN) and were housed in tiestalls with free access to water over the 16-week trial. Diets were offered once daily at $1000 \mathrm{~h}$. Orts were collected and weights recorded at $0900 \mathrm{~h}$, and feeding rate was adjusted daily to yield orts between 5 to $10 \%$ of intake (DM basis). Weekly composite samples $(0.5 \mathrm{~kg})$ were taken from daily samples of alfalfa silage, corn silage, high-moisture corn, TMR, and orts, and stored at $-20^{\circ} \mathrm{C}$ until analysis. Weekly samples of SBM, CM, soy hulls, and urea were also taken and stored at room temperature. The DM concentration was determined in weekly composites of $\mathrm{AS}, \mathrm{CS}$, and high-moisture corn (HMSC) by drying at $60^{\circ} \mathrm{C}$ for $48 \mathrm{~h}$; SBM, CM, and soy hull samples were dried at $105^{\circ} \mathrm{C}$ according to AOAC (1990; method 967.03). Feed ingredients were also analyzed weekly for total $\mathrm{N}$ using a combustion assay (Leco FP-2000 N Analyzer, Leco Instruments 
Inc., St. Joseph, MI) according to AOAC International (2005; method 990.13). These ingredient DM and N values were used to adjust dietary composition weekly to maintain constant DM proportions from each feed ingredient and CP concentration in each diet. The DMI was computed daily based on the $60^{\circ} \mathrm{C}$ DM determinations for TMR and orts. After drying, ingredients and TMR were ground to pass through a 1-mm screen (Wiley mill, Arthur H. Thomas, Philadelphia, PA). Samples were analyzed for DM (method 934.01), ash, and OM (method 938.08) according to AOAC (1990), and total $\mathrm{N}$ as described previously. Samples were sequentially analyzed for NDF, ADF, and ADIN after treatment with thermo-stable $\alpha$-amylase and $\mathrm{Na}_{2} \mathrm{SO}_{3}$ according to Van Soest et al. (1991), with adaptations for the Ankom ${ }^{200}$ Fiber Analyzer (Ankom Technology, Macedon, NY). For NDIN determination, the same procedure described for NDF was used, but thermostable $\alpha$-amylase was omitted.

Cows were milked twice daily at 0500 and $1700 \mathrm{~h}$, and milk yield was recorded at each milking time during the entire trial. Milk samples were taken at both milkings (a.m. and p.m.) on 2 consecutive days during wk 3 and 4 of each period. Individual milk samples were analyzed for fat, protein, lactose, SNF, and MUN by infrared analysis (AgSource, Verona, WI) with a spectrum analyzer (FT6000; Foss North America Inc., Eden Prairie, MN) using AOAC (1990) method 972.16. Concentrations and yields of milk fat, true protein, lactose, SNF, and MUN were calculated as weighted means based on daily milk yields on each sampling day and a single mean computed for each cow in each period. Yields of $3.5 \%$ FCM were calculated according to Sklan et al. (1992), and yields of ECM were calculated as described by Krause and Combs (2003). Efficiencies of feed conversion were calculated for each cow over wk 3 and 4 of each period by dividing the average yield of actual milk and ECM by the respective DMI. Efficiency of feed $\mathrm{N}$ utilization was calculated for each cow by dividing mean milk $\mathrm{N}$ output (milk true protein/6.38) by mean $\mathrm{N}$ intake, assuming no net deposit or mobilization of $\mathrm{N}$ from body tissues. Cows were weighed on 3 consecutive days at the beginning and at the end of each period to estimate BW change.

Spot fecal grab samples directly from rectum and spot urine samples via manual stimulation of the vulva were collected at the end of each period from each cow $6 \mathrm{~h}$ before and $6 \mathrm{~h}$ after feeding. Fecal samples were dried in a forced-draft oven $\left(60^{\circ} \mathrm{C} ; 72 \mathrm{~h}\right)$ and ground to pass through a 1-mm screen (Wiley mill). Equal DM amounts from each fecal subsample were combined to obtain 1 composite sample for each period. Fecal samples were analyzed for total DM, ash, OM, N, NDF, $\mathrm{ADF}$. Indigestible ADF, which is the $\mathrm{ADF}$ residue remaining after 12-d in situ incubation, was used as an internal marker to estimate fecal output and apparent total-tract digestibility (Cochran et al., 1986; Huhtanen et al., 1994). Briefly, samples of feed, orts, and feces were placed into $4 \mathrm{~cm} \times 5 \mathrm{~cm}$ F57 Ankom filter bags $(25-\mu \mathrm{m}$ porosity; Ankom Technology, Macedon, NY). Thereafter, Ankom bags (approximately 0.4 $\mathrm{g})$ were incubated in duplicate for $288 \mathrm{~h}$ in the rumen of 2 ruminally cannulated, mid-lactation, multiparous Holstein cow fed a TMR containing (DM basis) AS (31.3\%), CS (28.9\%), HMSC (25.1\%), SBM (8.4\%), soyhulls $(3.93 \%)$, and mineral and vitamin premix $(2.45 \%)$. After incubation, bags were removed, soaked in ice water for 15 min, rinsed using a washing machine,

Table 1. Chemical composition of major dietary ingredients ${ }^{1}$

\begin{tabular}{|c|c|c|c|c|c|c|}
\hline Item & $\mathrm{AS}$ & CS & HMSC & SBM & $\mathrm{CM}$ & Soy hulls \\
\hline DM, $\%$ as fed & 35.4 & 35.0 & 73.8 & 90.7 & 92.1 & 95.1 \\
\hline $\mathrm{CP}, \%$ of $\mathrm{DM}$ & 20.3 & 7.07 & 7.93 & 50.5 & 39.7 & 10.5 \\
\hline $\mathrm{NDF}, \%$ of $\mathrm{DM}$ & 39.1 & 42.2 & 11.6 & 8.8 & 28.0 & 62.5 \\
\hline $\mathrm{ADF}, \%$ of $\mathrm{DM}$ & 30.3 & 24.6 & 6.5 & 4.8 & 19.9 & 43.4 \\
\hline NDIN, $\%$ of total $\mathrm{N}$ & 10.2 & 18.0 & 6.8 & 6.7 & 16.2 & 40.6 \\
\hline ADIN, $\%$ of total $\mathrm{N}$ & 4.5 & 3.8 & 1.6 & 0.3 & 5.9 & 5.9 \\
\hline $\mathrm{B}_{2},{ }^{2} \%$ of total $\mathrm{N}$ & 5.7 & 14.2 & 5.2 & 6.4 & 10.3 & 34.8 \\
\hline NPN, $\%$ of total $\mathrm{N}$ & 62.4 & 49.0 & 42.9 & - & - & - \\
\hline $\mathrm{NH}_{3}, \%$ of total $\mathrm{N}$ & 8.4 & 11.0 & 5.7 & - & - & - \\
\hline Total AA N ${ }^{3} \%$ of total $\mathrm{N}$ & 39.5 & 32.3 & 27.2 & - & - & - \\
\hline Peptide N, ${ }^{4} \%$ of total $\mathrm{N}$ & 14.5 & 5.8 & 10.0 & - & - & - \\
\hline $\mathrm{pH}$ & 4.69 & 3.82 & 4.10 & & & \\
\hline \multicolumn{7}{|c|}{$\begin{array}{l}{ }^{1} \mathrm{AS}=\text { alfalfa silage; } \mathrm{CS}=\text { corn silage; HMSC }=\text { high-moisture corn; } \mathrm{SBM}=\text { solvent-extracted soybean meal; } \\
\mathrm{CM}=\text { solvent-extracted canola meal. } \\
{ }^{2} \text { Fraction } \mathrm{B}_{2}=\text { NDIN }-\mathrm{ADIN} \text { (Higgs et al., } 2015 \text { ). } \\
{ }^{3} \text { Total AA N computed assuming } 40.3 \mathrm{~mol} \text { of total free AA } / \mathrm{mg} \text { of } \mathrm{N} \text { in alfalfa and corn silages (Broderick, } \\
1987 \text { ). }\end{array}$} \\
\hline
\end{tabular}


dried in a forced-air oven set at $60^{\circ} \mathrm{C}$ for $48 \mathrm{~h}$. Samples were then analyzed for ADF concentration as previously described. Total-tract nutrient digestibilities were calculated from indigestible ADF and nutrient concentrations in the orts-adjusted diet and feces using the following equation: apparent total-tract nutrient digestibility $(\%$ of nutrient intake $)=100-[($ TMR marker concentration/fecal marker concentration) $\times($ fecal nutrient concentration/TMR nutrient concentration)].

Urine samples were acidified immediately after collection by diluting 1 volume of urine with 4 volumes of $0.072 \mathrm{~N} \mathrm{H}_{2} \mathrm{SO}_{4}$ and stored at $-20^{\circ} \mathrm{C}$ until analysis. Before the analysis, urine samples were thawed at room temperature and filtered through Whatman No. 1 filter paper (General Electric, Boston, MA). Filtrates were analyzed for creatinine concentration using a picric acid method (Oser, 1965) adapted to flow-injection analysis (Lachat Quik-Chem 8000 FIA; Lachat Instruments, Milwaukee, WI), and for total $\mathrm{N}$ using a $\mathrm{N}$ analyzer (Leco FP-2000 N Analyzer; Leco Instruments Inc.). In addition, filtrates were analyzed for urea concentration with a colorimetric method (Broderick and Clayton, 1997). Daily urine volume was calculated based on individual BW and using creatinine excretion rate of 29 $\mathrm{mg} / \mathrm{kg}$ of BW (Valadares et al., 1999). Urinary urea $\mathrm{N}$ and total $\mathrm{N}$ excretion were calculated based on their urinary concentrations multiplied by estimated daily urine volume.

Table 2. Dietary ingredients and chemical composition of experimental diets (\% of DM unless otherwise stated)

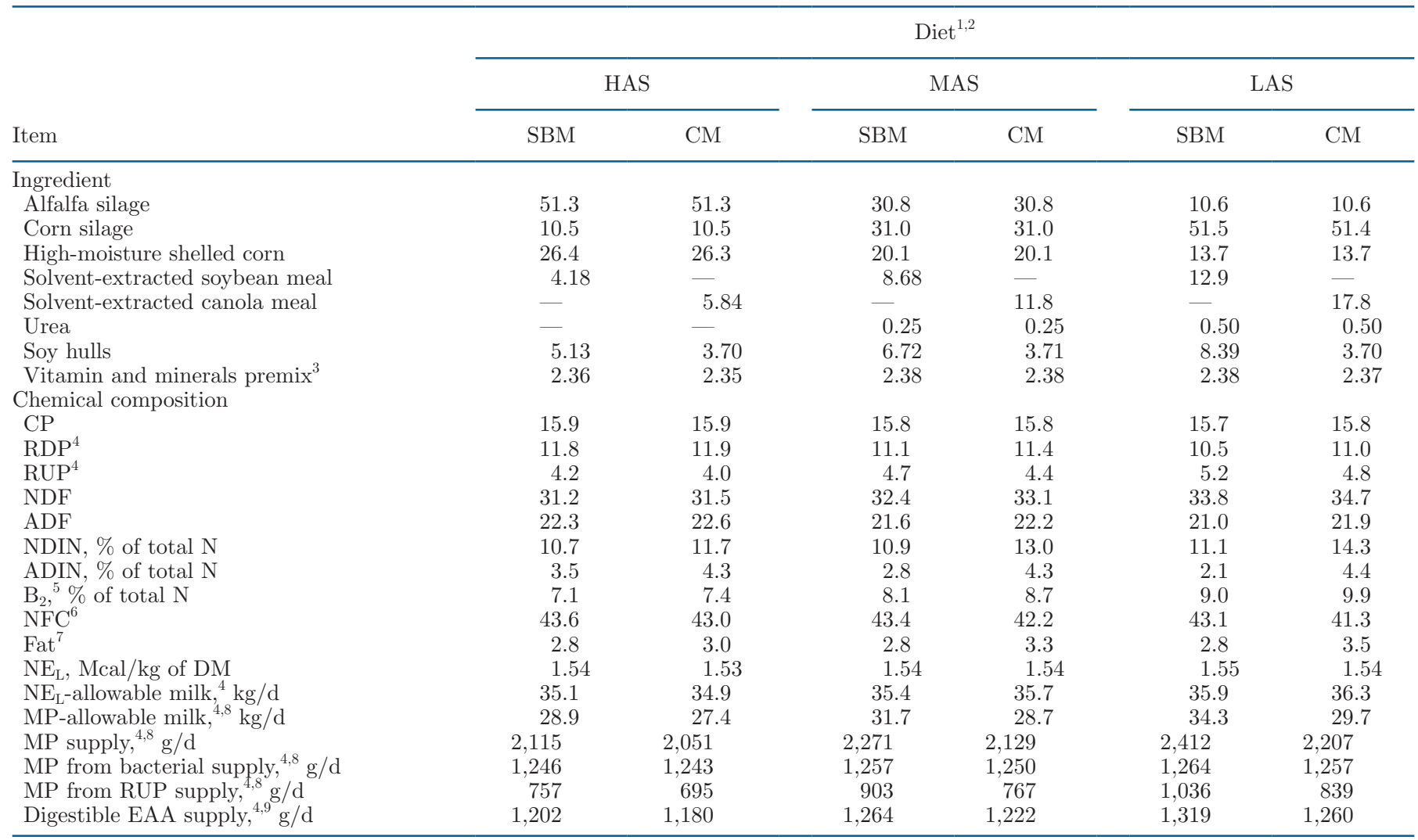

${ }^{1}$ Forage sources in different proportions: HAS $=$ high alfalfa silage, $50 \%$ alfalfa silage and $10 \%$ corn silage; MAS $=$ medium alfalfa silage, $30 \%$ alfalfa silage and $30 \%$ corn silage; LAS = low alfalfa silage, $10 \%$ alfalfa silage and $50 \%$ corn silage.

${ }^{2}$ Protein supplement: $\mathrm{SBM}=$ soybean meal; $\mathrm{CM}=$ canola meal.

${ }^{3}$ Provided (per $\mathrm{kg}$ of DM): $56 \mathrm{mg}$ of $\mathrm{Zn}, 46 \mathrm{mg}$ of $\mathrm{Mn}, 22 \mathrm{mg}$ of Fe, $12 \mathrm{mg}$ of $\mathrm{Cu}, 0.9 \mathrm{mg}$ of I, $0.4 \mathrm{mg}$ of Co, $0.3 \mathrm{mg}$ of Se, 6,440 IU of vitamin A, 2,000 IU of vitamin D, 16 IU of vitamin $\mathrm{E}$, and $12 \mathrm{mg}$ of monensin.

${ }^{4}$ Estimated according to the NRC (2001) model using average observed DMI $(23.7 \mathrm{~kg} / \mathrm{d})$ and ingredient composition from Table 1 and NRC tables.

${ }^{5}$ Fraction $\mathrm{B}_{2}=$ NDIN - ADIN (Higgs et al., 2015).

${ }^{6} \mathrm{NFC}=100-(\% \mathrm{NDF}+\% \mathrm{CP}+\%$ fat $+\%$ ash $)$ according to the NRC (2001) model.

${ }^{7}$ Fat concentration of individual dietary ingredients were used from the NRC (2001) nutrient composition tables.

${ }^{8}$ MP estimated using the NRC (2001) model.

${ }^{9}$ Digestible EAA supply to duodenum g/d, estimated using the NRC (2001) model. 


\section{Statistical Analysis}

Mean production data were analyzed as a cyclic changeover design in a $3 \times 2$ arrangement of treatments (design 16, Table 4, Davis and Hall, 1969; Supplemental Figure S1, https://doi.org/10.3168/jds.2019-16947) with 3 proportions of AS and CS supplemented with 2 different protein supplements using the MIXED procedure of SAS (2013; SAS Institute Inc., Cary, NC). The following model was used to fit the data to assess effects of protein source (SBM or CM) and forage source proportion on production, excretion, and apparent digestibility:

$$
\begin{aligned}
\mathrm{Y}_{\mathrm{ijk} k \mathrm{~m}}= & \mu+\mathrm{B}_{\mathrm{i}}+\mathrm{P}_{\mathrm{j}}+\mathrm{PS}_{\mathrm{k}}+\mathrm{FS}_{\mathrm{l}}+\mathrm{P} \times \mathrm{PS}_{\mathrm{jk}} \\
& +\mathrm{P} \times \mathrm{FS}_{\mathrm{j} 1}+\mathrm{C}_{\mathrm{m}}\left(\mathrm{B}_{\mathrm{i}}\right)+\mathrm{E}_{\mathrm{ijklm}},
\end{aligned}
$$

where $Y_{\mathrm{ijklm}}=$ dependent variable, $\mu=$ overall mean, $\mathrm{B}_{\mathrm{i}}=$ effect of block $\mathrm{i}(\mathrm{i}=1$ to 8$), \mathrm{P}_{\mathrm{j}}=$ effect of period $\mathrm{j}(\mathrm{j}=1$ to 4$), \mathrm{PS}_{\mathrm{k}}=$ effect of protein supplement $\mathrm{k}(\mathrm{k}$ $=1$ to 2$), \mathrm{FS}_{1}=$ effect of forage source $1(1=1$ to 3$)$, $\mathrm{P} \times \mathrm{PS}_{\mathrm{jk}}=$ interaction of period $\mathrm{j}$ and protein source $\mathrm{k}, \mathrm{P} \times \mathrm{FS}_{\mathrm{jl}}=$ interaction of period $\mathrm{j}$ and forage source $1, \mathrm{C}_{\mathrm{m}}\left(\mathrm{B}_{\mathrm{i}}\right)=$ effect of cow $\mathrm{m}$ within block $\mathrm{i}$, and $\mathrm{E}_{\mathrm{ijklm}}=$ residual error. All terms were considered fixed, except for $\mathrm{C}_{\mathrm{m}}\left(\mathrm{B}_{\mathrm{i}}\right)$ and $\mathrm{E}_{\mathrm{ijk} k \mathrm{~m}}$, which were considered random. Effect of protein supplement is represented as SBM vs. $\mathrm{CM}$; and effects of forage source proportion is represented as follows: high AS (HAS) $=50 \%$ alfalfa silage and $10 \%$ corn silage; medium AS (MAS) $=30 \%$ alfalfa silage and $30 \%$ corn silage; low AS (LAS) $=10 \%$ alfalfa silage and $50 \%$ corn silage. When a significant $F$-test was detected for interactions, comparisons were made using the PDIFF option test. For all models, least squares means are reported, significance is declared at $P \leq 0.05$, and trends are declared at $0.05<P \leq 0.10$.

\section{RESULTS AND DISCUSSION}

\section{Dietary Ingredient and Chemical Composition of the Diets}

Dietary ingredients and chemical composition of the ingredients and diets fed in the present study are shown in Tables 1 and 2, respectively. Due to differences in total $\mathrm{CP}$ and $\mathrm{CP}$ fractions between $\mathrm{AS}$ and $\mathrm{CS}(\mathrm{CP}=$ 20.3 vs. $7.07 \%$ of DM; NPN $=62.4$ vs. $49.0 \%$ of total $\mathrm{N}), 0.25 \%$ of DM (diets MAS-SBM and MAS-CM) and $0.5 \%$ of DM (diets LAS-SBM and LAS-CM) of urea was added in these diets to provide the same $\mathrm{CP}$ and to partly account for the reduced NPN with increasing CS as alfalfa silage was removed from the diets (dietary treatments $\mathrm{CP}=15.8 \pm 0.1$, average $\pm \mathrm{SD}$ ). Because of the differences in NDF concentration between SBM and $\mathrm{CM}(\mathrm{NDF}=8.8$ vs. $28.0 \%$ of DM, respectively), the amount of soy hulls added in SBM diets was greater (mean $6.8 \%$ of DM) than in CM diets (mean $3.7 \%$ of $\mathrm{DM}$ ) to balance the fiber concentration of the diets $(\mathrm{NDF}=32.5 \pm 1.1$ vs. $33.1 \pm 1.3$, on average, for SBM and $\mathrm{CM}$ diets, respectively). We observed $\mathrm{pH}$ values of 4.69 and 3.82 , and ammonia $\mathrm{N}$ concentration of 8.4 and $11.0 \%$ of total N, for AS and CS, respectively. These values are within typical ranges reported for CS and AS and indicate that the silages were well fermented (Kung and Shaver, 2001).

The NRC (2001) tables and model indicated that CM had lower nutritive value than SBM as a protein supplement. In the present study, on average MP, MP allowable milk, and duodenal essential AA flow estimated using NRC (2001) were all greater for SBM diets compared with CM diets (Table 2). Furthermore, as the proportion of CS increased in the diet, the RUP supply predicted by the NRC (2001) increased for SBM diets compared with CM $(+32,+79$, and $+111 \mathrm{~g} / \mathrm{d}$ for diets HAS-SBM, MAS-SBM, and LAS-SBM, respectively). However, these values were not in agreement with the overall animal performance results when cows were fed CM compared with SBM diets in the present trial (see next section) and in previous work (Brito and Broderick, 2007; Broderick et al., 2015). Therefore, in agreement with other studies (Huhtanen et al., 2011; Martineau et al., 2013; Paula et al., 2018) we can speculate that the NRC (2001) model underestimates MP supply when $\mathrm{CM}$ is fed to lactating dairy cows.

\section{Milk Production, N Excretion, and Digestion}

One of the objectives of the present study was to evaluate the interaction between the different ratios of AS and CS in diets and SBM or CM as protein supplement on performance of lactating dairy cows. However, because significant interactions were not found on milk production traits $(P>0.25)$, results are discussed as main effects of protein supplement (SBM vs. CM) and dietary forage proportion of AS and CS.

Dry matter intake was not affected by either PS or FS $(P>0.40)$. Contrary to the results of the present study, Brito and Broderick (2007) and Broderick et al. (2015) observed an increase in DMI of 0.7 and $0.4 \mathrm{~kg} / \mathrm{d}$, respectively, for cows fed CM diet compared with SBM. Martineau et al. (2013), in a meta-analysis evaluating diets supplemented with CM compared with other protein supplements, also observed an increase of $0.24 \mathrm{~kg} / \mathrm{d}$ for cows fed CM diets. In their meta-analysis study, Huhtanen et al. (2011) compared CM with SBM diets and speculated that the increase in DMI for cows fed CM could be due to a better supply of essential AA that could enhance milk yield and, as a consequence, 
cows would have to eat more to supply the greater requirement of energy to support the increased milk yield. However, this hypothesis is still untested, and other studies did not detect differences in DMI between lactating cows fed CM and SBM diets (Rinne et al., 2015; Paula et al., 2018; Sánchez-Duarte et al., 2019). Overall our results demonstrated that, regardless of the proportion of AS or CS in the diet, cows fed diets with $\mathrm{CM}$ yielded $0.8 \mathrm{~kg} / \mathrm{d}$ more milk $(P=0.03)$ and $20 \mathrm{~g} / \mathrm{d}$ more milk protein $(P=0.03)$, and tended to yield more lactose $(P=0.06)$ compared with cows fed diets with SBM (Table 3). Similar to our findings, Broderick et al. (2015) observed greater milk and ECM yield $(+1 \mathrm{~kg} / \mathrm{d})$ for cows fed CM compared with SBM. Although not significant $(P=0.72)$, it is worth noting that for diets with 50:10 AS to CS ratio, cows fed CM yielded $1.2 \mathrm{~kg}$ more milk/d, whereas for diets with 30:30 and 10:50 AS to CS, cows fed CM diets yielded, respectively, 0.8 and $0.6 \mathrm{~kg}$ more milk/d compared with SBM diets. We have shown in previous experiments that possible reasons for improved cow performance on CM compared with SBM are increased DMI or post-ruminal rather than ruminal effects (Paula et al., 2017, 2018). However, in the present study we did not observe increased DMI on $\mathrm{CM}$, as discussed earlier; the greater performance in the present study may be due to a better AA profile in the RUP fraction, resulting in a better supply of essential AA in the MP. For example, Maxin et al. (2013) compared the AA ruminal degradability of CM vs. SBM, and observed greater concentration of Met, Lys, and His in the RUP fraction for CM compared with SBM and other protein supplements. Furthermore, in a meta-analysis of data obtained from peer-reviewed articles comparing diets supplemented with CM vs. other protein supplements, Martineau et al. (2014) observed greater plasma concentration of total essential AA for cows fed diets supplemented with CM compared with other protein supplements. Also, in their study comparing different levels of $\mathrm{CP}$ in diets with red clover and grass silage as forage sources and rapeseed meal or expeller SBM as protein supplement, Rinne et al. (2015) reported greater plasma Met concentration for rapeseed meal diets.

In the present study a reduction $(P<0.01)$ of $8 \%$ was observed in MUN concentration for cows fed CM diets compared with SBM (Table 3). Although we did not observe $(P=0.80)$ a protein supplement effect on excreted urine volume $(\mathrm{L} / \mathrm{d})$, a reduction in total

Table 3. Effects of dietary protein supplement sources and forage source ratio on production traits of lactating dairy cows

\begin{tabular}{|c|c|c|c|c|c|c|c|c|c|c|}
\hline Item & \multicolumn{6}{|c|}{$\operatorname{Diet}^{1,2}$} & SEM & \multicolumn{3}{|c|}{ Probability $^{3}$} \\
\hline DMI, kg/d & 23.7 & 23.6 & 23.9 & 24.2 & 23.1 & 23.8 & 0.46 & 0.40 & 0.41 & 0.58 \\
\hline BW change, $\mathrm{kg} / \mathrm{d}$ & 0.12 & 0.38 & 0.48 & 0.53 & 0.13 & 0.35 & 0.11 & 0.04 & 0.01 & 0.68 \\
\hline \multicolumn{11}{|l|}{ Production } \\
\hline $\mathrm{ECM},{ }^{5} \mathrm{~kg} / \mathrm{d}$ & 33.3 & 34.5 & 36.2 & 36.4 & 37.0 & 37.2 & 0.66 & 0.25 & $<0.01$ & 0.60 \\
\hline \multicolumn{11}{|l|}{ Feed efficiency } \\
\hline Milk/DMI & 1.47 & 1.50 & 1.56 & 1.59 & 1.71 & 1.68 & 0.04 & 0.67 & $<0.01$ & 0.61 \\
\hline ECM/DMI & 1.43 & 1.48 & 1.53 & 1.53 & 1.66 & 1.61 & 0.04 & 0.98 & $<0.01$ & 0.41 \\
\hline \multicolumn{11}{|l|}{ Milk component } \\
\hline Milk fat, $\%$ & 4.08 & 4.09 & 4.02 & 3.92 & 3.89 & 3.77 & 0.09 & 0.21 & $<0.01$ & 0.70 \\
\hline Milk fat, $\mathrm{kg} / \mathrm{d}$ & 1.38 & 1.43 & 1.48 & 1.47 & 1.48 & 1.47 & 0.04 & 0.73 & 0.02 & 0.64 \\
\hline $\mathrm{SNF}, \mathrm{kg} / \mathrm{d}$ & 2.94 & 3.04 & 3.23 & 3.28 & 3.87 & 3.44 & 0.05 & 0.04 & $<0.01$ & 0.72 \\
\hline MUN, mg/dL & 14.2 & 13.5 & 13.9 & 12.4 & 14.1 & 12.8 & 0.29 & $<0.01$ & 0.05 & 0.25 \\
\hline
\end{tabular}

${ }^{1}$ Forage sources in different proportions: HAS = high alfalfa silage, $50 \%$ alfalfa silage and $10 \%$ corn silage; MAS $=$ medium alfalfa silage, $30 \%$ alfalfa silage and 30\% corn silage; LAS = low alfalfa silage, $10 \%$ alfalfa silage and $50 \%$ corn silage.

${ }^{2}$ Protein supplement: $\mathrm{SBM}=$ soybean meal, $\mathrm{CM}=$ canola meal.

${ }^{3}$ Probability of treatment effects: PS = effects of protein supplement, SBM vs. CM diets; FS = effect of forage sources in different proportions; $\mathrm{PS} \times \mathrm{FS}=$ interaction between protein and forage source.

${ }^{4} \mathrm{FCM}=0.4318 \times$ milk yield $+16.23 \times$ fat yield (Sklan et al., 1992).

${ }^{5} \mathrm{ECM}=$ milk yield, $\mathrm{kg} / \mathrm{d} \times[(0.0929 \times$ percentage of fat $)+(0.0563 \times$ percentage of true protein $)+(0.0395 \times$ percentage of lactose $)] / 0.749$ (Krause and Combs, 2003). 
urinary $\mathrm{N}(P=0.05)$ of $4 \%$ and of $6 \%$ in urinary urea $\mathrm{N}$ excretion $(P=0.03)$ was observed for cows fed CM diets compared with SBM (Table 4). This indicates an overall improvement in $\mathrm{N}$ utilization by lactating dairy cows fed diets with CM compared with SBM diets. Furthermore, our results are in line with previous studies that have consistently reported a decrease in MUN concentration and $\mathrm{N}$ excretion for $\mathrm{CM}$ diets compared with SBM (Martineau et al., 2014; Broderick et al., 2015; Rinne et al., 2015). Moreover, dietary ingredients such as CM that can reduce total $\mathrm{N}$ excretion, especially urinary urea $\mathrm{N}$ excretion, are important from an environment standpoint because excess $\mathrm{N}$ excretion and ammonia emissions from manure have negative environmental effects.

Milk yield was greatest $(P<0.01)$ for cows fed LAS, intermediate for MAS, and lowest for HAS (38.6, 37.2, and $34.7 \mathrm{~kg} / \mathrm{d}$, respectively). The same response was observed for ECM, feed efficiency (ECM/DMI), and milk protein concentration and yield. However, milk fat concentration was greatest for cows fed HAS, intermediate for MAS, and lowest for LAS (4.09, 3.99, and $3.83 \%$, respectively). Milk fat yield, 3.5\% FCM, and milk lactose concentration and yield were lower for cows fed HAS compared with MAS and LAS $(P<0.05$; Table 3). Hassanat et al. (2013) evaluated performance of cows fed diets with AS:CS ratios of 56:0, 28.2:28.2, and 0:56.4, DM basis. They observed a quadratic ef- fect in yields of milk, ECM, milk protein, and lactose, and a linear increase for milk protein concentration and yield, whereas milk fat concentration and yield linearly decreased as CS gradually replaced AS in the diet. On the other hand, Brito and Broderick (2006) tested diets with AS:CS ratios of 51:0, 37:10, 24:27, and 10:40 (DM basis) for lactating dairy cows, and they observed a linear decrease in DMI, milk yield, and milk fat yield as AS was replaced by greater proportions of CS in the diet. The difference among studies may be due to the chemical composition of the diets. In the present study and that of Hassanat et al. (2013), the NDF concentration of the diets were greater on average $(32.8 \pm 1.2$ and $29.7 \pm 0.9 \%$ of DM, respectively) compared with the results of Brito and Broderick (2006; $23.7 \pm 0.2 \%$ of DM), and the NFC concentration were lower in the present study and in that of Hassant et al. (2013; 42.8 \pm 0.8 and $41.9 \pm 4.0 \%$ of DM, respectively) compared with Brito and Broderick (2006; $49.0 \pm 0.4, \%$ of DM). Therefore, based on our results, we may speculate that when NDF concentration is between 33 and $29 \%$, and NFC concentration is between 41 and $43 \%$ in the total diet, cows' performance may be enhanced in diets with a moderate or greater proportion of CS compared with a diet with greater proportions of AS.

Total urine volume decreased $(P<0.01)$ as the proportion of AS decreased in the diet $(41.8,40.4$, and $35 \mathrm{~L} / \mathrm{d}$, on average, for diets HAS, MAS, and LAS,

Table 4. Effects of dietary protein supplement sources and forage source ratio on nutrient digestibility and $\mathrm{N}$ excretion of lactating dairy cows

\begin{tabular}{|c|c|c|c|c|c|c|c|c|c|c|}
\hline \multirow{2}{*}{ Item } & \multicolumn{6}{|c|}{$\operatorname{Diet}^{1,2}$} & \multirow{2}{*}{ SEM } & & & \\
\hline & \multicolumn{2}{|c|}{ HAS } & \multicolumn{2}{|c|}{ MAS } & \multicolumn{2}{|c|}{ LAS } & & \multicolumn{3}{|c|}{ Probability $^{3}$} \\
\hline $\mathrm{N}$ intake, $\mathrm{g} / \mathrm{d}$ & 604 & 601 & 605 & 611 & 581 & 600 & 11.5 & 0.39 & 0.27 & 0.58 \\
\hline Urine volume, $\mathrm{L} / \mathrm{d}$ & 40.7 & 42.9 & 41.6 & 39.3 & 35.3 & 34.5 & 2.2 & 0.80 & $<0.01$ & 0.43 \\
\hline \multicolumn{11}{|l|}{ Urinary excretion } \\
\hline Urea $N, g / d$ & 198 & 194 & 199 & 188 & 195 & 179 & 6.0 & $<0.01$ & 0.24 & 0.56 \\
\hline Urea $\mathrm{N}, \%$ of total urinary $\mathrm{N}$ & 82.3 & 83.1 & 78.6 & 76.6 & 78.0 & 77.2 & 2.0 & 0.24 & 0.08 & 0.79 \\
\hline Urea $N, \%$ of $\mathrm{N}$ intake & 32.9 & 31.9 & 33.3 & 30.8 & 33.9 & 30.4 & 1.1 & $<0.01$ & 0.98 & 0.33 \\
\hline \multicolumn{11}{|l|}{ Fecal N excretion } \\
\hline $\mathrm{N}, \mathrm{g} / \mathrm{d}$ & 182 & 197 & 189 & 185 & 179 & 171 & 5.5 & 0.72 & 0.02 & 0.08 \\
\hline $\mathrm{N}, \%$ of $\mathrm{N}$ intake & 30.1 & 32.8 & 31.1 & 29.9 & 31.1 & 28.7 & 0.6 & 0.59 & 0.04 & $<0.01$ \\
\hline \multicolumn{11}{|l|}{ Apparent digestibility, \% } \\
\hline
\end{tabular}

\footnotetext{
${ }^{\mathrm{a}-\mathrm{c}}$ Mean values in the same row with different superscripts differ $(P<0.01)$ for the interaction between forage source and protein supplement. ${ }^{1}$ Forage sources in different proportions: HAS $=$ high alfalfa silage, $50 \%$ alfalfa silage and $10 \%$ corn silage; MAS $=$ medium alfalfa silage, $30 \%$ alfalfa silage and $30 \%$ corn silage; LAS = low alfalfa silage, $10 \%$ alfalfa silage and $50 \%$ corn silage.

${ }^{2}$ Protein supplement: $\mathrm{SBM}=$ soybean meal, $\mathrm{CM}=$ canola meal.

${ }^{3}$ Probability of treatment effects: PS = effects of protein supplement, SBM vs. CM diets; FS = effect of forage sources in different proportions; $\mathrm{PS} \times \mathrm{FS}=$ interaction between protein and forage source.
} 
respectively). Our results are in line with those of Brito and Broderick (2006), who also observed a decrease in urine volume for diets with greater proportions of CS compared with diets with AS, which was likely due to the greater concentration of potassium in AS compared with CS (NRC, 2001).

Forage source did not affect $\mathrm{N}$ intake, total $\mathrm{N}$, or urea $\mathrm{N}$ urinary excretion $(P>0.05)$. Contrary to our results, Brito and Broderick (2006) observed a decrease in urinary total $\mathrm{N}$ and urea $\mathrm{N}$ excretion for diets with greater proportions of CS compared with AS, and Broderick et al. (2007) observed an increase in total N and urea $\mathrm{N}$ urinary excretion for cows fed an AS-based diet compared with red clover silage-based diets. In both studies, contrary to the present trial, differences in urine $\mathrm{N}$ excretion were related to the increased $\mathrm{N}$ intake for cows fed AS-based diets, which may explain the lack of effect on urine $\mathrm{N}$ excretion in the present study. Cows fed LAS diets excreted on average $13 \mathrm{~g}$ of $\mathrm{N} / \mathrm{d}$ less compared with HAS and MAS diets $(P=$ 0.02 ). This result may be explained by greater apparent $\mathrm{CP}$ total-tract digestibility, because CP digestibility of the LAS diet was on average 2.3 and $1 \%$ greater than HAS and MAS diets, respectively.

We observed an interaction $(P<0.01)$ between protein supplement and forage source for apparent totaltract digestibility of DM, OM, CP, and NDF (Table 4). Dietary treatment HAS-CM had the lowest apparent total-tract digestibility for DM, OM, CP, and NDF. Treatments LAS-CM and HAS-SBM had greater DM, $\mathrm{OM}$, and NDF digestibility compared with MAS-SBM and MAS-CM, whereas CP digestibility was only greater for LAS-CM compared with MAS-SBM. Interactions between protein source and AS proportion were confined to apparent nutrient digestibility, intake of digestible $\mathrm{DM}$ and $\mathrm{OM}$, and fecal $\mathrm{N}$ as a proportion of $\mathrm{N}$ intake. Amounts of the 2 protein concentrates added to the diet increased from 4.2 to $12.9 \%$ of DM (SBM, with $9 \% \mathrm{NDF})$ and from 5.8 to $17.8 \%$ of DM (CM, with $28 \% \mathrm{NDF}$ ) as CS replaced AS in the diet. Moreover, dietary urea increased from 0 to 0.25 to $0.50 \%$ as $\mathrm{AS}$ was reduced from 50 to $10 \%$ of dietary DM. Additionally, dietary NDF increased by about 1.4 percentage units with each reduction in proportion of AS in the diet. Hence, sources and digestibility of dietary NFC and particularly NDF were altered in this manner. We believe that these changes largely account for the small observed interactions on forage proportion and protein supplement on traits related to digestibility. Furthermore, previous studies have found inconsistent results for total-tract digestibility when AS and CS diets were supplemented with SBM or CM. For example, Brito and Broderick (2007) observed greater NDF digestibility for cows fed CM diets compared with SBM, but no differ- ence in digestibility of other nutrients. However, Paula et al. (2018) observed greater total-tract digestibility for cows fed CM diets compared with SBM. Overall, based on the results of the present study and other studies, the differences in total-tract digestibility likely had only minor effects on cow performance.

\section{CONCLUSIONS}

Based on the results of the present study, replacing SBM with CM increased yields of milk, milk protein, and lactose, and decreased MUN and urinary N excretion of lactating dairy cows, regardless of the ratios of alfalfa silage to corn silage. Regarding the forage source proportion, our results indicate that a balance between alfalfa and corn silages (e.g., CS:AS ratio of 30:30\% of the total diet, DM basis) with $33 \%$ NDF and $43 \%$ NFC, or greater proportions of CS to AS (e.g., CS:AS ratio of $50: 10 \%$ of the total diet, DM basis) with $31 \%$ NDF and $43 \%$ NFC, enhanced yields of milk and milk protein, ECM, and milk protein concentration compared with cows fed diets with a greater proportion of AS (e.g., CS:AS ratio of 10:50\% of the total diet, DM basis).

\section{ACKNOWLEDGMENTS}

The authors thank the Canola Council of Canada (Winnipeg, MB, Canada) for partial funding support for this research; the farm crew for harvesting and storing the feedstuffs used in this trial and Kurt Pickar for feeding and animal care at the US Dairy Forage Research Center Farm (Prairie du Sac, WI); Wendy Radloff and Mary Becker of the US Dairy Forage Research Center (Madison, WI) for conducting laboratory analyses and for assisting with sample collection; and Peter Crump of the University of Wisconsin-Madison for assisting with statistical analyses. The authors have not stated any conflicts of interest.

\section{REFERENCES}

AOAC (Association of Official Analytical Chemists). 1990. Official Methods of Analysis. 15th ed. AOAC, Arlington, VA.

AOAC International. 2005. Official Methods of Analysis. 18th ed. AOAC International, Gaithersburg, MD.

Brito, A. F., and G. A. Broderick. 2006. Effect of varying dietary ratios of alfalfa silage to corn silage on production and nitrogen utilization in lactating dairy cows. J. Dairy Sci. 89:3924-3938. https: //doi.org/10.3168/jds.S0022-0302(06)72435-3.

Brito, A. F., and G. A. Broderick. 2007. Effects of different protein supplements on milk production and nutrient utilization in lactating dairy cows. J. Dairy Sci. 90:1816-1827. https://doi.org/10 $.3168 /$ jds.2006-558.

Brito, A. F., G. A. Broderick, and S. M. Reynal. 2006. Effect of varying dietary ratios of alfalfa silage to corn silage on omasal flow and microbial protein synthesis in dairy cows. J. Dairy Sci. 89:39393953. https://doi.org/10.3168/jds.S0022-0302(06)72436-5. 
Broderick, G. A. 1987. Determination of protein degradation rates using a rumen in vitro system containing inhibitors of microbial nitrogen metabolism. Br. J. Nutr. 58:463-475. https://doi.org/10 .1079 /bjn19870114.

Broderick, G. A., A. F. Brito, and J. J. O. Colmenero. 2007. Effects of feeding formate-treated alfalfa silage or red clover silage on the production of lactating dairy cows. J. Dairy Sci. 90:1378-1391. https://doi.org/10.3168/jds.S0022-0302(07)71624-7.

Broderick, G. A., and M. K. Clayton. 1997. A statistical evaluation of animal and nutritional factors influencing concentrations of milk urea nitrogen. J. Dairy Sci. 80:2964-2971. https://doi.org/10 .3168/jds.S0022-0302(97)76262-3.

Broderick, G. A., S. Colombini, S. Costa, M. A. Karsli, and A. P. Faciola. 2016. Chemical and ruminal in vitro evaluation of Canadian canola meals produced over 4 years. J. Dairy Sci. 99:7956-7970. https://doi.org/10.3168/jds.2016-11000.

Broderick, G. A., A. P. Faciola, and L. E. Armentano. 2015. Replacing dietary soybean meal with canola meal improves production and efficiency of lactating dairy cows. J. Dairy Sci. 98:5672-5687. https://doi.org/10.3168/jds.2015-9563.

Cochran, R. C., D. C. Adams, J. D. Wallace, and M. L. Galyean. 1986. Predicting digestibility of different diets with internal markers: evaluation of four potential markers. J. Anim. Sci. 63:1476-1483. https://doi.org/10.2527/jas1986.6351476x.

Davis, A. W., and W. B. Hall. 1969. Cyclic change-over designs. Biometrika 56:283-293. https://doi.org/10.1093/biomet/56.2.283.

Dhiman, T. R., and L. D. Satter. 1997. Yield response of dairy cows fed different proportions of alfalfa silage and corn silage. J. Dairy Sci. 80:2069-2082. https://doi.org/10.3168/jds.S0022-0302(97)76152 -6 .

Edmunds, B., K. H. Südekum, R. Bennett, A. Schröder, H. Spiekers, and F. J. Schwarz. 2013. The amino acid composition of rumenundegradable protein: A comparison between forages. J. Dairy Sci. 96:4568-4577. https://doi.org/10.3168/jds.2012-6536.

Groff, E. B., and Z. Wu. 2005. Milk production and nitrogen excretion of dairy cows fed different amounts of protein and varying proportions of alfalfa and corn silage. J. Dairy Sci. 88:3619-3632. https:/ /doi.org/10.3168/jds.S0022-0302(05)73047-2.

Hassanat, F., R. Gervais, C. Julien, D. I. Massé, A. Lettat, P. Y. Chouinard, H. V. Petit, and C. Benchaar. 2013. Replacing alfalfa silage with corn silage in dairy cow diets: Effects on enteric methane production, ruminal fermentation, digestion, $\mathrm{N}$ balance, and milk production. J. Dairy Sci. 96:4553-4567. https://doi.org/10 $.3168 /$ jds.2012-6480.

Higgs, R. J., L. E. Chase, D. A. Ross, and M. E. Van Amburgh. 2015 Updating the Cornell Net Carbohydrate and Protein System feed library and analyzing model sensitivity to feed inputs. J. Dairy Sci. 98:6340-6360. https://doi.org/10.3168/jds.2015-9379.

Huhtanen, P., M. Hetta, and C. Swensson. 2011. Evaluation of canola meal as a protein supplement for dairy cows: A review and a metaanalysis. Can. J. Anim. Sci. 91:529-543. https://doi.org/10.4141/ cjas2011-029.

Huhtanen, P., K. Kaustell, and S. Jaakkola. 1994. The use of internal markers to predict total digestibility and duodenal flow of nutrients in cattle given six different diets. Anim. Feed Sci. Technol. 48:211-227. https://doi.org/10.1016/0377-8401(94)90173-2.

Krause, K. M., and D. K. Combs. 2003. Effects of forage particle size, forage source, and grain fermentability on performance and ruminal pH in midlactation cows. J. Dairy Sci. 86:1382-1397. https:// doi.org/10.3168/jds.S0022-0302(03)73722-9.

Kung, L., and R. Shaver. 2001. Interpretation and use of silage fermentation analysis reports. Focus on Forage 3:1-5. https://fyi .extension.wisc.edu/forage/files/2016/10/Fermentation2.pdf.

Lavergne, S. and Oleson. F. 2018. Market Analysis Group/Grains and Oilseeds Division. Sector Development and Analysis Directorate/ Market and Industry Services Branch. Canada: Outlook for Prin- cipal Field Crops. Agriculture and Agri-Food Canada. January 2018. https://www.reportlinker.com/p05740444/Future-of-Global -Rapeseed-Oil-Market-To-Growth-Opportunities-Competition -And-Outlook-Of-Rapeseed-Oil-by-Applications-and-Regions -Report.html.

Martineau, R., D. R. Ouellet, and H. Lapierre. 2013. Feeding canola meal to dairy cows: A meta-analysis on lactational responses. J. Dairy Sci. 96:1701-1714. https://doi.org/10.3168/jds.2012-5740.

Martineau, R., D. R. Ouellet, and H. Lapierre. 2014. The effect of feeding canola meal on concentrations of plasma amino acids. J. Dairy Sci. 97:1603-1610. https://doi.org/10.3168/jds.2013-7125.

Maxin, G., D. Ouellet, and H. Lapierre. 2013. Ruminal degradability of dry matter, crude protein, and amino acids in soybean meal, canola meal, corn, and wheat dried distillers grains. J. Dairy Sci. 96:5151-5160. https://doi.org/10.3168/jds.2012-6392.

NRC (National Research Council). 2001. Nutrient Requirements of Dairy Cattle. 7th rev. ed. Natl. Acad. Press, Washington, DC.

Oser, B. L. 1965. Hawk's Physiological Chemistry. 14th ed. McGrawHill, New York, NY.

Patton, R. A., A. N. Hristov, and H. Lapierre. 2014. Protein feeding and balancing for amino acids in lactating dairy cattle. Vet. Clin. North Am. Food Anim. Pract. 30:599-621. https://doi.org/ 10.1016/j.cvfa.2014.07.005.

Paula, E. M., G. A. Broderick, M. A. C. Danes, N. E. Lobos, G. I. Zanton, and A. P. Faciola. 2018. Effects of replacing soybean meal with canola meal or treated canola meal on ruminal digestion, omasal nutrient flow, and performance in lactating dairy cows. J. Dairy Sci. 101:328-339. https://doi.org/10.3168/jds.2017-13392.

Paula, E. M., H. F. Monteiro, L. G. Silva, P. D. B. Benedeti, J. L. P. Daniel, T. Shenkoru, G. A. Broderick, and A. P. Faciola. 2017. Effects of replacing soybean meal with canola meal differing in rumen-undegradable protein content on ruminal fermentation and gas production kinetics using 2 in vitro systems. J. Dairy Sci. 100:5281-5292. https://doi.org/10.3168/jds.2016-12301.

Rinne, M., K. Kuoppala, S. Ahvenjärvi, and A. Vanhatalo. 2015. Dairy cow responses to graded levels of rapeseed and soya bean expeller supplementation on a red clover/grass silage-based diet. Animal 9:1958-1969. https://doi.org/10.1017/S1751731115001263.

Sánchez-Duarte, J. I., K. F. Kalscheur, D. P. Casper, and A. D. García. 2019. Performance of dairy cows fed diets formulated at 2 starch concentrations with either canola meal or soybean meal as the protein supplement. J. Dairy Sci. 102:7970-7979. https://doi .org/10.3168/jds.2018-15760.

SAS. 2013. 9.4-Guide to Software Updates. SAS Institute Inc., Cary, $\mathrm{NC}$.

Sklan, D., R. Ashkenazi, A. Braun, A. Devorin, and K. Tabori. 1992. Fatty acids, calcium soaps of fatty acids, and cottonseeds fed to high yielding cows. J. Dairy Sci. 75:2463-2472. https://doi.org/10 $.3168 / j d s . S 0022-0302(92) 78008-4$.

Valadares, R. F., G. A. Broderick, S. C. Valadares Filho, and M. K. Clayton. 1999. Effect of replacing alfalfa silage with high moisture corn on ruminal protein synthesis estimated from excretion of total purine derivatives. J. Dairy Sci. 82:2686-2696. https://doi.org/10 .3168/jds.S0022-0302(99)75525-6.

Van Soest, P. J., J. B. Robertson, and B. A. Lewis. 1991. Methods for dietary fiber, neutral detergent fiber, and nonstarch polysaccharides in relation to animal nutrition. J. Dairy Sci. 74:3583-3597. https://doi.org/10.3168/jds.S0022-0302(91)78551-2.

\section{ORCIDS}

E. M. Paula @ https://orcid.org/0000-0002-1891-6303

G. A. Broderick ๑ https://orcid.org/0000-0002-3466-9728

A. P. Faciola ๑ https://orcid.org/0000-0003-0935-6233 